\title{
Hastane tercihinde kişisel, kurumsal, çevresel faktörler ve marka imajının etkisi: İstanbul ilinde bir araştırma ${ }^{1}$ The effects of personal, corporate, environmental factors and brand image on the hospital preference: A research in İstanbul province
}

\author{
Şakir Erdem² \\ Ahmet Tuzcuoğlu
}

\begin{abstract}
${ }^{1}$ Bu çalışma, Ahmet Tuzcuoğlu tarafından Prof. Dr. Şakir Erdem'in danışmanlığında hazırlanan "Hastane Tercihinde Kişisel, Kurumsal, Çevresel Faktörler ve Marka İmajının Etkisi: İstanbul İlinde Bir Araştırma" başlıklı Marmara Üniversitesi Üretim Yönetimi ve Pazarlama Doktora Tezi'nden türetilmiştir.
\end{abstract}

2 Prof. Dr., Marmara Üniversitesi İşletme Fakültesi, İstanbul, Türkiye, serdem@marmara.edu.tr

ORCID: 0000-0003-2145-3060

${ }^{3}$ Arş. Gör., İstanbul Üniversitesi Siyasal Bilgiler Fakültesi, İstanbul, Türkiye, atuzcuoglu@istanbul.edu.tr

ORCID: 0000-0003-2972-2069

\section{Sorumlu Yazar/Corresponding Author:}

Ahmet Tuzcuoğlu,

İstanbul Üniversitesi Siyasal Bilgiler Fakültesi, İstanbul, Türkiye, atuzcuoglu@istanbul.edu.tr

\section{Başvuru/Submitted: 8/12/2020}

Revizyon/Revised: 4/04/2021

Kabul/Accepted: 12/04/2021

Yayın/Online Published: 25/04/2021

Atıf/Citation: Erdem, Ş., \& Tuzcuoğlu, A., Hastane tercihinde kişisel, kurumsal, çevresel faktörler ve marka imajının etkisi: İstanbul ilinde bir araştırma, tujom (2021) 6 (1):51-69, doi:

https://doi.org/10.30685/tujom.v6i1.103
Öz

Bireylerin en önemli ihtiyaçlarından biri sağlıktır. Sağlıklı olmak için, bireysel çabalar yeterli olmadığı durumda, sağlık kuruluşlarından profesyonel hizmet almak gerekmektedir. Doğru sağlık kuruluşunu tercih etmek için her birey belirli bir karar alma sürecinden geçmektedir. Bu çalışmada amaç, bireylerin sağlık kuruluşu tercihine etki eden kişisel, kurumsal, çevresel faktörler ile kurumların marka imajının sağlık kuruluşu tercihine etkisini incelemektir. Bu amaçla, ortaya konan keşifsel model çerçevesinde ilk olarak uzmanlarla görüşme yapılmış, takiben yapılan pilot çalışma sonrasında anket uygulamasına geçilmiştir. Kolayda örneklemenin kullanıldığı İstanbul'da yapılan araştırmada, yüz yüze anket yöntemiyle toplamda 657 ankete ulaşılmış, bunlardan 628 adedinin kullanılabilir nitelikte olduğu tespit edilip, analize dahil edilmiştir. Katılımcıların en fazla tercih ettiği özel hastane sorulmuş olup, en fazla tercih edilen AC ve MP hastaneleri özelinde analizler yapılmıştır. Yapılan analizlerin sonucunda; “Hastane Marka İmajı”nın "Hastane Tercihi”ni olumlu yönde etkilediği; "Sağlıklı Yaşam Davranışı" ile "Kurumsal ve Çevresel Etmenler"in "Hastane Tercihi" üzerinde net bir etkisinin olmadığı, ancak alt boyutlarda farklı gruplarda farklı anlamlı etkilerin olduğu tespit edilmiştir.

Anahtar Kelimeler: Hastane Tercihi, Sağlıklı Yaşam Davranışı, Kurumsal ve Çevresel Faktörler, Hastane Marka İmajı

Jel Kodları: M310

\begin{abstract}
One of the most critical needs of individuals is health. To be healthy, when individual efforts are not sufficient, it is necessary to get professional service from health institutions. Each individual goes through a particular decision-making process in order to choose the right health institution. This study aims to examine the personal, corporate, environmental factors and the brand image of the health institution's choice. For this purpose, within the experimental model framework, the experts were first interviewed, and then a questionnaire was applied after the pilot study. In the study conducted in Istanbul, where convenience sampling was used, a total of 657 questionnaires were reached by face to face survey method; 628 were found to be usable and included in the analysis. The most preferred private hospital by the participants was asked, and the data sets of the most preferred hospitals, which are AC and MP, were analyzed accordingly. As a result of the analysis, It was determined that "Hospital Brand Image" positively affected "Hospital Preference"; "Healthy Living Behavior" and "Corporate and Environmental Factors" did not have an apparent effect on "Hospital Preference", but different significant effects in different groups in sub-dimensions.
\end{abstract}

Keywords: Hospital Preference, Healthy Living Behavior, Corporate and Environmental Factors, Hospital Brand Image

Jel Codes: M310 


\section{Extended Abstract}

\section{The effects of personal, corporate, environmental factors and brand image on the hospital preference: A research in İstanbul province}

\section{Literature}

\section{Research subject}

The research aims to examine personal, corporate, environmental factors and hospital brand image that affect hospital preferences. Accordingly, The Healthy Living Behavior Scale introduced by Walker et al. (1987) and revised by Walker and HillPolerecky (1996) as an individual agent; Institutional and Environmental Factors Scale developed by Lee, Shih and Chung (2008); Hospital Brand Image Scale developed by Wu (2011) and the purchase intention scale developed by Coyle and Thorson (2001) was used.

\section{Research purpose and importance}

It has revealed the importance of "how consumers choose the most suitable for them among increasing alternatives" thanks to the diversification of people's needs and rapid improvements in the healthcare industry. When the relevant literature in this field is examined; It seems that there is not much study. It was preferred to make an investigation by considering the basic assumptions within the framework of this study. Accordingly, the effect of personal, corporate and environmental factors in health institution choice in this preference process has been tried to be examined.

\section{Contribution of the article to the literature}

In the literature review, no study was encountered in which the subjects included in the research model were examined together within the framework of a model. This paper is a pioneer in the field, and it is thought to make a significant contribution to the related literature. Besides, although the results that will emerge are preliminary and in need of improvement, it is thought that they will contribute significantly to the development of the sectoral perspective.

\section{Design and method}

\section{Research type}

It is an article that includes research conducted within the framework of a model.

\section{Research problems}

The factors affecting hospital preferences are examined with the research.

\section{Data collection method}

Within the framework of the research, firstly, a model was presented based on literature analysis. This model was evaluated qualitatively by interviews with experts. Following this, after the necessary arrangements are made, and a total of 657 questionnaires were reached by face-to-face survey method, 628 were found to be usable and included in the analysis.

\section{Quantitative/qualitative analysis}

In the first stage of the research, the model's accuracy, which was revealed by interviews with the experts, was tested. The data obtained with the questionnaire applied afterwards; Reliability analysis, confirmatory factor analysis and exploratory factor analysis were performed, and finally, the structural equation model was applied.

\section{Research model}

The research model is below:

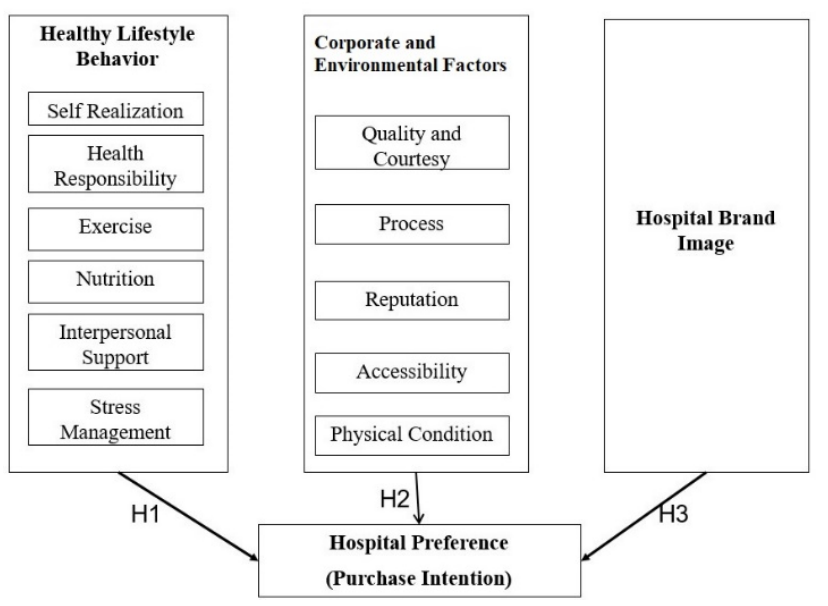

Figure 1: Research Model 


\section{Research hypotheses}

The research hypotheses are below:

H1: Healthy lifestyle behaviour affects hospital preference.

H1a: Self-realization affects hospital preference.

H1b: Health responsibility affects hospital preference.

H1c: Exercise affects hospital preference.

H1d: Nutrition affects hospital preference.

H1e: Interpersonal support affects hospital preference.

H1f: Stress management affects hospital preference.

$\mathrm{H} 2$ : Corporate and environmental factors affect hospital preference.

H2a: Quality and courtesy affect hospital preference.

$\mathrm{H} 2 \mathrm{~b}$ : Process affects hospital preference.

H2c: Reputation affects hospital preference.

H2d: Accessibility affects hospital preference.

H2e: Physical condition affects hospital preference.

H3: Hospital brand image affects hospital preference.

Findings and discussion

\section{Findings as a result of analysis}

The most preferred private hospital by the participants was asked, and the data sets of the most preferred hospitals, which are $\mathrm{AC}$ and MP, were analyzed accordingly. As a result of the analysis, It was determined that "Hospital Brand Image" positively affected "Hospital Preference"; "Healthy Living Behavior" and "Corporate and Environmental Factors" did not have an apparent effect on "Hospital Preference", but different significant effects in different groups in sub-dimensions.

\section{Hypothesis test results}

Hypothesis testing results are summarized in the table below:

Table 1: Hypothesis testing results

\begin{tabular}{|l|l|l|c|}
\hline \multicolumn{1}{|c|}{ Hypotheses } & ALL DATA & AC & MP \\
\hline H1: Healthy lifestyle behaviour affects hospital preference. & $\begin{array}{l}\text { PARTIALLY } \\
\text { ACCEPTED }\end{array}$ & PARTIALLY ACCEPTED & PARTIALLY ACCEPTED \\
\hline H1a: Self-realization affects hospital preference. & REJECTED & REJECTED & ACCEPTED \\
\hline H1b: Health responsibility affects hospital preference. & ACCEPTED & ACCEPTED & ACCEPTED \\
\hline H1c: Exercise affects hospital preference. & REJECTED & REJECTED & REJECTED \\
\hline H1d: Nutrition affects hospital preference. & REJECTED & ACCEPTED & REJECTED \\
\hline H1e: Interpersonal support affects hospital preference. & ACCEPTED & ACCEPTED & REJECTED \\
\hline H1f: Stress management affects hospital preference. & ACCEPTED & REJECTED & ACCEPTED \\
\hline H2: Corporate and environmental factors affect hospital preference. & REJECTED & PARTIALLY ACCEPTED & PARTIALLY ACCEPTED \\
\hline H2a: Quality and courtesy affect hospital preference. & REJECTED & REJECTED & ACCEPTED \\
\hline H2b: Process affects hospital preference. & REJECTED & ACCEPTED & REJECTED \\
\hline H2c: Reputation affects hospital preference. & REJECTED & REJECTED & REJECTED \\
\hline H2d: Accessibility affects hospital preference. & REJECTED & ACCEPTED & ACCEPTED \\
\hline H2e: Physical condition affects hospital preference. & REJECTED & REJECTED & REJECTED \\
\hline H3: Hospital brand image affects hospital preference. & ACCEPTED & ACCEPTED & ACCEPTED \\
\hline
\end{tabular}

\section{Discussing the findings with the literature}

The studies in the literature on the factors affecting the choice of hospitals are examined under the title of corporate and environmental factors in this study. It is a pioneer study in determining how people approach healthy life and examining its effect on hospital choice collectively by including the concept of health behaviour. 
When viewed on a scale basis, Findings of Healthy Living Behavior (Esin, 1997), Hospital Branding Image (Wu, 2011) and Hospital Preference (Coyle \& Thorson, 2001) reached similar results to those in the literature. However, in the study, which was chosen as the basis for Corporate and Environmental Factors, the results of the 19-variable scale developed by Lee, Shih and Chung (2008), respectively, "convenience and economy", "reputation and privilege", "quality and courtesy" and "timeliness". While it is put forward in four essential factors; the factors of "Quality and Courtesy", "Process", "Reputation", "Accessibility" and "Physical Condition" were determined, respectively, in this study. Similar factors are observed in different studies in the literature (Tüfekci \& Asığbulmuş, 2016; Şantaş, Kurşun \& Kar, 2016; Kayaoğlu \& Gülmez, 2020).

\section{Conclusion, recommendation and limitations}

\section{Results of the article}

According to the findings obtained as a result of the analysis made within the framework of the research, while some of the hypotheses formed are accepted, it is seen that some are rejected. The point that draws attention here is in all analyzes; it is observed that the "Hospital Brand Image" positively affects the "Hospital Preference". This shows how positively the hospital administrators receive their work on the brand. Apart from this, unlike the studies conducted in the literature regarding hospital preference, it was determined that health behaviour, which is a personal factor in this study, has statistically significant factors affecting hospital preference.

\section{Suggestions based on results}

It is thought that the adaptation of each of the scales used here, adding other concepts that can be effective in the process, conducting more comprehensive studies to include other units in hospital service processes will make significant contributions to both the literature and the sector. Within the scope of this study, data were collected before the pandemic period; it can be predicted that this process may change the perceptions about health. Therefore, a change can be observed with the implementation of this study during or after the pandemic.

\section{Limitations of the article}

The first of the limitations of the study is related to its sample. The research is applied to all consumers who live in Istanbul and make their own health institution choices. However, it is not possible to reach all consumers due to both time and cost constraints. Therefore, the research results are not generalizable due to the sampling structure.

One of the most significant constraints encountered in the research process is that this model has not been tested before. The study is a pioneer. The research process was initiated by predicting basic models' framework that the model could produce statistically significant results.

One of the most critical constraints of the study is the study's design on hospital preference for the "general clinic service". Therefore, research to be conducted with the same participants for any different unit may reveal different results. 


\section{Giriş}

İnsanların doğuştan gelen temel ihtiyaçlarından biri olan sağllk üzerine değerlendirmeler yaparken ilk olarak sağlığın tanımına bakmak gerekmektedir. Akademik yazında karşılaşılan tanımların 5 açıdan incelendiği görülmektedir (Abelin, Brzezinski ve Carstairs,1987, s. 10-17; Walker, Sechrist ve Pender, 1987, s. 76-77; Fertman ve Allensworth, 2010, s. 4-8; Pender, Murdaugh ve Parsons, 2015, s. 1015):

- Sağlığı Koruma Üzerine Odaklanan Tanımlar: İçsel ve dışsal etkenlerle bireyin karşılaştığı durumlara/çevreye uyumu ve tepkilerini içerir.

- Sağlığı Geliştirme Üzerine Odaklanan Tanımlar: Yaşamın her döneminde yüksek düzeyli iyilik haline ulaşabilmek adına edinilen deneyimleri içerir.

- Sağlığı Geliştirme ve Koruma Üzerine Odaklanan Tanımlar: Bir iyilik hissi, yeteneğinin en iyisini yapabilme kapasitesi ve çevresinden gelen çeşitli durumlara uyum sağlama esnekliğini içerir.

- Sağlığı bir sahiplik ifadesi olarak gören tanımlar: Farklı roller ve günlük yaşamın içindeki istekler çerçevesinde çeşitli faaliyetlerde bulunma kapasitesini içerir.

- Bütünleşik sağlık görüşüne göre tanımlar: Fizyolojik bakış açısının yanında biyo medikal modeller ve halk sağlığı modellerini entegre olarak içerir.

Sağlık alanında var olan tanımlamaların başında Dünya Sağlık Örgütü'nün (DSÖ / WHO) üyelerinin 22 Temmuz 1946 tarihinde imzaladığı anayasada yer alan tanımdır. Buna göre Sağlık; "sadece hastalık ve sakatlığın olmayışı değil; fiziksel, ruhsal ve sosyal yönden tam bir iyilik halidir" ("Dünya Sağlık Örgütü", 2018).

Tam bir iyilik haline ulaşabilmek için bireylere sunulan sağlık hizmetleri; koruyucu sağlık hizmetleri, tedavi edici sağlık hizmetleri, rehabilite edici sağlık hizmetleri ve sağlığın geliştirilmesi olarak sınıflandırılmaktadır (Kavuncubaşı, 2000, s.35). Ülkemizde sağlık hizmetleri kamu hastaneleri, özel hastaneler, yerel yönetimlere ait hastaneler, bazı sivil toplum kuruluşlarına ait kurum ve kuruluşlar, farklı bakanlıkların değişik kuruluşları ve azınlıklara ait bazı sağlık kuruluşları tarafından sunulmaktadır (Öztürk, 2000, s.151).

Ülke politikalarında öncelikli alanlar arasında yer alan sağlık sektörüne yatırım sürekli artmakta ve sağlik hizmeti sunan kurumlar çeşitlenmektedir. Bu durum, pazarlama açısından incelenmesi gereken önemli gelişmeleri ortaya çıkarmaktadır. Çeşitlenen sağlık sektöründen hizmet alan tüketicilerin karar verme sürecinin incelenmesi, hem sunulacak olan hizmetin kalitesinin artması hem de sektör temsilcilerinin tüketicileri anlayarak onların talep ve isteklerini karşılamaya yönelik doğru yatırımlar yapabilmesi adına önem taşımaktadır.

Literatür incelendiğinde karşılaşılan çalışmalarda, hastane tercihine etki eden etmenler daha ziyade hastanelerin sunduğu hizmetlere karşı algılamalar üzerine odaklanmıştır (bu çalışmalara ilgili başlık altında da değinilmektedir). Bu çalışma ile farklı bakış açısı da eklenerek bireylerin sağlık konusundaki bireysel davranışları da incelenen bir modelle yaklaşım geliştirilmiştir.

\section{Literatür taraması}

Çalışma kapsamında, hastane tercihine etki eden kişisel etmenler "Sağlık Davranışı" başlığı ile, hastanenin sunmuş olduğu imkanlar ve koşullar "Kurumsal ve Çevresel Faktörler" başlığı ile, bu hastanelerin sahip oldukları imaj algıları ise "Hastane Marka İmajı" alt başlıklarında literatür incelenmesi olarak yer almaktadır.

\section{Sağlık davranışı}

Çalışmada hastane tercihine etki eden kişisel faktörlerin incelendiği sağlık davranışları, en geniş anlamıyla; sağlıkla ilgili sosyal değişim, politika geliştirme ve uygulama, yetenekler geliştirme ve yaşam kalitesini arttırmaya yönelik bireylerin, grupların ve kuruluşların tüm eylemlerini içerir (Parkerson, Connis, Broadhead, Patrick, Taylor ve Tse, 1993, s. 638).

Sağlık davranışları gerek hastalık durumundan önce gerekse de sonraki süreçte, bir dizi eylem içermektedir. Bireylere olumlu sağlık davranışı kazandırma programlarının temelinde, bireyin 
davranışlarını etkileyen faktörlerin tanımlanması gerekmektedir. Bu nedenle, sağlık davranışı sürecini değerlendiren birçok model geliştirilmiştir. Bu modeller, bir davranış konusunda bilimsel ve gerçekçi değerlendirme yapmaya olanak sağlamaktadır (Pender, Murdaugh ve Parsons, 2015, s.27)

Literatürde yer alan sağlık davranışı modellerinin daha çok davranış değişikliği oluşturma üzerine kurulduğu görülmektedir. Literatürdeki sağlık davranışı modelleri aşağıda maddeler halinde incelenmektedir:

- Sağlıkta Kontrol Odağı (Health Locus of Control- HLC) yaklaşımının kökenleri Rotter'in (1954) sosyal öğrenme teorisinde yer almaktadır. Sosyal öğrenme teorisinin temel prensibi, belirli bir durumda meydana gelen bir davranış olasılığının, bireyin davranışın belirli bir pekiştirmeye yol açacağı beklentisinin ve pekiştirmenin değerinin ölçülmesinin ortak bir işlevi olmasıdır (Rotter, 1966, s.2). Wallston ve arkadaşları (1976, s.581) ise, iç ve dış kontrol odağını içeren Sağlık Kontrol Ölçeği (HLC) geliştirmişlerdir. Bu çalışmanın devamındaysa, 1978 yılında Çok Boyutlu Sağlık Kontrol Ölçeği'ni (MHLC) geliştirmişlerdir. Buna göre sağlık kontrol odağı ölçümü tek boyutta (iç kontrol) yapılırken, daha sonraki çalışmalarında 3 boyuttan bahsetmişlerdir (Wallston, Smith, King, Forsberg, Wallston ve Nagy, 1983, s.378);

o İnsanın sağlığının kendisinin kontrolünde olduğu - İç Kontrol

o Kendisi tarafından kontrol edilemediği kader olduğu - Şans

o Sağlığın başka kişilerin kontrolünde olduğu (doktor veya yakın çevre) - Dış Kontrol

Wallston, 1992'de makalesinde Rotter'in Sosyal Öğrenme Teorisindeki ve kendi geliştirdikleri ölçeğe gelen eleştirileri değerlendirmiştir. Bu gelişmelerle birlikte Sağlık Kontrol Odağında da bu alanda yapılan diğer çalışmaları da göz önünde bulundurup, değişiklikler önermiştir (1992: s.196-197); buna göre sağlık değeri ve mevcut sağlık durumu iç sağlık kontrolünde aracı rol oynamaktadır.

- Gerçekçi Olmayan İyimserlik: Weinstein (1980: s.810) yaptığı bir araştırmada; katılımcıların sorunla karşılaşmadan o sorunun kendileri için geçerli olmadığını, "bana bir şey olmaz" düşüncesi ile soruna yaklaştıklarını görmüştür. Bu davranış "gerçekçi olmayan iyimserlik (unrealistic optimism)" olarak isimlendirilmiştir. Bu duruma etki eden beş temel faktör (Weinstein, 1980, s.818-819):

o Olumlu durumların olumsuz durumlara oranla daha cazibeli olması

o Sorunun nadir olduğuna dair inanç

o İlgili sorun ile ilgili daha önce bir tecrübenin olmaması

o Sorunun kişilerin tercihleri ile engellenebileceği inancı,

o İlgili sorunun şimdiye kadar çıkmamasından dolayı ileride de çıkmayacağı inancı

$\mathrm{Bu}$ düşüncenin sağlıkla ilgili bir sorunla karşılaşmadan herhangi bir sağlık kurumuna başvurmak istememe durumunu ortaya çıkardığını belirtmektedir. Bu anlamda katılımcıların sadece tedavi edici sağlık hizmetlerine ihtiyaç duyduğu belirtilmektedir.

- Temellerini 1985'te ortaya koyan Deci ve Ryan (1985: s.117-118; 2000: s.241)'nn Öz Belirleme Kuramının (Self-Determination Theory- SDT) temelinde güdüler yer almaktadır. Güdülenme ile ilgili üç seviyeden bahsetmektedirler:

o İçsel güdülenme: güzel yiyecekler yemek ve arkadaşlarla konuşmak gibi kişi ile ilgili amaçları gerçekleştirmekle ilgilidir. İyilik hali ve sağlıkla ilgili davranışların sürdürülmesi eğilimidir.

o Dışsal güdülenme: arkadaşları memnun etme gibi güdülerdir. Daha az kişisel doyum ve dolayısıyla sağlık davranışlarından kaçınmayla ilgilidir.

o Güdülenmeme: yaptıklarından hiçbir sonuç beklememe, dolayısıyla yapmak istememe durumudur.

Bir diğer ifadeyle insanlar için hayat bir anlam ifade etmez; ya da kendileri veya çevreleri için yaşarlar. Kendini daha ön plana koyanlar (içsel güdülerin baskın olduğu) sağlık davranışlarına önem vermektedir. 
- Değisșim Așamaları Modeli (Transtheoretical model- TTM), 1980'lerin başında davranış değişikliğini, özellikle de bağımlılık davranışına bağlı değişiklikleri anlamanın bir yolu olarak geliştirilmiştir (Prochasta ve DiClemente, 1982, s.276). Modelin yapısında; Değişim Aşamaları (Ön Düşünce, Niyet, Hazırlık, Hareket, Koruma, Sonlandırma), Değişim Süreçleri (Bilinçlendirme, Rahatlama, Bireysel Yeniden Değerlendirme, Çevresel Yeniden Değerlendirme, Kurtuluş, Yardım, Karşı Şartlanma, Güçlendirme, Uyarıcı Kontrolü, Sosyal Kurtuluş), Karar Dengesi (Artılar, Eksiler) ve Öz-Yeterlik (Güven, Cezbedicilik) maddeleri yer almaktadır (Glanz, Rimer ve Viswanath, 2008, s.98-99). Sözü edilen aşamalar; değişim sürecinde bireyin durumuyla ilgili olarak bireyin tutum, niyet ve davranışlarını yansıtmaktadır. Bu model sigara içme, alkol kullanımı, egzersiz ve sağlık taraması gibi sağlıkla ilgili konularda kullanılmıştır. Kişilerin düzenli olarak sağlık kontrolüne gitmesi de bu model çerçevesinde değerlendirilebilmektedir.

- Sağlıkta Eylem Süreci Yaklaşımı (SESY- Health Action Process Approach- HAPA) 1992 yılında ortaya konmuştur. Schwarzer ve arkadaşları (2003, s.2-3) sağlık inançlarının ve davranışlarının anlaşılması için "güdülenme ve eylem aşamalarının" olduğu zamansal bir yaklaşım geliştirmiştir. Hem niyetleri hem de gerçek davranışları içeren bir modeldir. Bu modelin temelinde karar verme süreci ile eylemin sürdürülmesi sürecinin ayrımı yer almaktadır. $\mathrm{Bu}$ modele göre güdülenme aşamasındaki bileşenler (Schwarzer, Sniehotta, Lippke, Luszczynska, Scholz, Schüz, Wegner ve Ziegelmann, 2003, s.3; Schwarzer, 2008, s.6-7):

o Öz Yeterlik: kişilerin kendisine olan güven

o Sonuç beklentileri: oluşacak davranış değişikliği sonucu gerek kişisel değişimler gerekse de çevrenin vereceği tepkiler

o Tehdit algısı: hastalığın ciddiyeti ve kişinin hastalığa yakalanma ihtimali üzerine inançlardan oluşmaktadır.

Bu modele göre sonuç; eylem niyetinin oluşmasıdır. Eylem aşaması bilişsel, durumsal ve davranışsal faktörlerden oluşmaktadır. Schwarzer, bu modeli ile niyetler ve davranışlar arasında köprü olduğunu, bunların temelinde de öz yeterlilik olduğunu vurgulamaktadır.

- Sağlık İnanç Modeli (SIM- Health Belief Model - HBM) önleyici sağlık davranışlarının ve akutkronik hastalığı olan insanların tedaviye verdikleri davranışsal tepkilere göre ilk olarak 1950'lerde Amerikan halk sağlığı araştırmacıları tarafından geliştirilmiştir. Rosenstock 1966'da ilk olarak sistematik hale getirmiştir. 1970 ve 1980'lerde gelişmeye devam eden modelin bileşenleri (Glanz, Rimer ve Viswanath, 2008, s.48); algılanan yatkınlık, algılanan ciddiyet, algılanan yararlar, algılanan bedeller, eylemin ipuçları ve öz yeterliktir. Bir bireyin bir hastalı̆̆ı önlemek için harekete geçebilmesi için inanması gereken durumlar (Rosenstock, 1974, s.330):

o Kişilerin şahsen söz konusu hastalığa duyarlı olduğu,

o Hastalığın ortaya çıkması durumda hayatına olumsuz etkileri olacağı,

o Belirli bir eylemde bulunmanın, aslında hastalığa karşı duyarlılığı azaltarak veya hastalık ortaya çıkarsa, şiddetini azaltarak faydalı olacağı,

bu yüzden psikolojik engellerin üstesinden gelinmesi gerektiğidir.

- Rogers 1975'te Sağlık İnanç Modeli'ne ek faktörler ekleyerek Koruyucu Motivasyon Kuramı'nı (KMK -Protection Motivation Theory - PMT) geliştirmiştir. Bu modelin ana katkısı SíM'in ilk modeline "Korku"nun ve sağlık davranışlarının anlaşılmasında ise duygusal bileşenin eklenmesidir. $\mathrm{Bu}$ modele göre; var olan bileşenler "Davranışsal niyetler"i oluşturmaktadır. Modelde bilgi kaynaklarının (çevresel (ikna, gözlem) - içsel (deneyimler)) bileşenlere etkisinden de bahsedilmektedir (Rogers, 1975, s.93; Conner ve Norman, 2005, s.82).

- Mantıksal Eylem Kuramı (MEK- Theory of Reasoned Action- TRA) tutum ve davranış ilişkisi ile ilgili tartışmanın merkezinde yer almaktadır (Fishbein ve Ajzen, 1975: 14-16). MEK hem inançları hem de bu inançların değerlendirilmesini içermektedir. Planlanmış Davranış Kuramı (PDK- Theory of Planned Behavior- TPB) Ajzen ve Madden tarafından MEK'in geliştirilmesi ile ortaya çıkmıştır (Ajzen, 1991, s.181). MEK'in öznel normları eklemesinin yanında davranışsal kontrol de eklenmiştir. Niyetleri 
"davranışlara yönelten eylem planları" olarak tanımlamakta olup, bunun temelindeki bileşenlerin; "Tutum", "Öznel Norm" ve "Algılanan Kontrol" olduğu belirtilmektedir.

Bu modele göre; inançlar tutumları (bireysel, çevresel, deneyimsel), tutumlar niyetleri, niyetler de davranışları oluşturmaktadır. Çevresel unsurların da süreci etkilediği görülmektedir. Sağlık davranışı bu modelde davranış değişikliği temelinde değerlendirilmektedir. MEK ile PDK arasındaki fark; MEK'te tutum ve öznel norm niyeti, niyet de davranışı etkilemektedir; PDK'da ise, tutum ve öznel normun yanında algilanan kontrol de niyeti etkilemektedir Madden, Ellen ve Ajzen (1992: s.4). Aynı zamanda algılanan kontrolün niyet üzerinden davranışa dolaylı etkisinin yanında davranışa olan doğrudan etkisi de modele eklenmiştir.

- Sağllğ 1 Gelistirme Modeli (SGM- Health Promotion Model - HPM), Pender tarafından ilk olarak 1982 yılında geliştirilmiş, 1996 yılında ise model revize edilmiştir (Pender, 2011, s.2). Beklenen değer ve sosyal öğrenme teorisine dayanan model, bireyin sağlığı geliştiren davranışlarını etkileyen bilişsel süreçlerin önemi $\urcorner n i$ açıklamaktadır. Bununla birlikte, modelin ana odağı, sekiz inançtır. Bu sekiz inanç, tıbbi müdahale için kritik noktalardır. Bu model kapsamında, hasta / müşteri ile işbirliği içinde çalışanlar, müşteriye sağlıklı bir yaşam tarzı elde etmesi için davranışlarını değiştirme konusunda yardımcı olabilmektedir. Modelde sağlı̆̆ı geliştiren davranışları etkileyen temel üç bileşen; "Bireysel Özellikler ve Deneyimler", "Davranışa Özgü Bilişler ve Etkileri" ve "Davranışsal Sonuç" basamaklarından oluşmaktadır. Sağlığı Geliştirme Modeli, özellikle sağlıklı bir yaşam tarzına entegre edildiğinde, iyileştirilmiş sağlık, gelişmiş fonksiyonel yetenek ve gelişimin her aşamasında daha iyi yaşam kalitesi ile sonuçlanmaktadır.

Sağlığı Geliştirme Yaşam Tarzı Davranışı Pender'in Sağlığı Geliştirme Modeli'ne dayandırılarak bireylerin sağlığı geliştirme davranışlarını ölçmek için Walker vd. (1987) tarafından geliştirilmiştir. Ölçek 1996 yılında revize edilmiş ve Sağlıklı Yaşam Tarzı Davranışları Ölçeği II olarak adlandırılmıştır (Walker ve Hill-Polerecky, 1996). Ölçek 52 madde ve altı faktörden oluşmaktadır. Bu faktörler (Bahar vd., 2008: 9); "Sağlık sorumluluğu", "Fiziksel aktivite", "Beslenme", “Manevi gelişim", "Kişilerarası ilişkiler" ve "Stres Yönetimi" dir.

\section{Kurumsal ve çevresel faktörler}

Akademik yazında sağlık kuruluşu tercihleri ile ilgili farklı çalışmalarda farklı kriterler kadar benzer kriterlere de yer verilmiştir. Boscarino ve Stelber (1982)'e göre etki eden faktörler: eve yakınlık, sürekli gittiği doktor, uzman doktorların varlığı, en iyi ekipmanlar, kaliteli imkanlar, tanıdık veya sevilen personel, kurum çalışanları ile geçmiş deneyim, daha uygun, dini inançlara saygı. Lane ve Lindquist (1988)'e göre sağlık kuruluşu tercihini belirleyen etmenler: personelin kalitesi, acil hizmetlerin kalitesi, bakım hizmetlerinin kalitesi, tamamlayıcı hizmetler, doktor tavsiyesi, modern ekipmanlar, nazik çalışanlar, iyi ortam, önceki deneyimler, maliyet, akrabaların tavsiyesi, eve yakınlık, özel odalar ve arkadaşların tavsiyesidir. Bu iki çalışmaya bakıldığında; her ikisinde de, verilen hizmetin kalitesi, eve yakınlık, maliyet, geçmiş deneyimler ve tavsiyeler üzerine odaklandıkları, Boscarino ve Stelber'in bunun yanında "dini inançlara saygı" kriterini de eklediği görülmektedir.

Ross, Steward ve Sinacore (1993: s.1138) çalışmalarında, hasta tercihlerini memnuniyet temelli bir model ile değerlendirmektedir. Sağlık memnuniyetinde öne çıkan üç boyut: kişilerarası bakım, teknik kalite ve bakıma erişim değerlendirmeleridir. Bunun yanında dört tercih bölümü tespit edilmiştir: kişilerarası bakım arayanlar, erişim/kalite arayanlar, ulaşılabilirlik arayanlar ve kalite arayanlar. Bu dört alt grup, bir dizi sosyodemografik, sağlık durumu ve sağlık hizmeti kullanım karakteri açısından anlamlı farklılık göstermekle birlikte, bu kesimler arasında tatmin açısından anlamlı bir farklılık bulunamamiştır.

Lee, Shih ve Chung (2008) hastane tercihine etki eden faktörleri 19 etmen 4 faktör altında incelenmiştir. Bu faktörler: "uygunluk ve ekonomiklilik", "itibar ve ayrıcalık", "kalite ve nezaket" ve "zamandalık (timeliness)". Bu şekilde kriter sayısını arttırmış ancak sonrasında faktörler altında organize ederek, daha kapsayıcı bir yapı ortaya koymuştur.

Tüfekci ve Asığbulmuş (2016: s.72) Isparta'da uyguladıkları anket sonucunda elde edilen verilerde yaptıkları faktör analizi sonucuna göre hastane tercihlerini 4 faktör altında toplamışlardır; hastane çalışanları, hastane işleyiş̧i, hastanenin fiziki koşulları ve diğer faktörler. Bunlar arasında yer alan etmenlerden hastane tercihinde en fazla etkili olanların sırayla; güven, uzman doktor tercihi ve 
memnuniyet olduğu tespit edilmiştir. Benzer olarak, Şantaş, Kurşun ve Kar (2016: s.17) aynı yıl yaptıkları araştırmalarında; hastane seçimine etki eden en önemli üç faktörün hastanenin hijyen ve temizliği, doktorların tutum ve davranışları ve hastanenin tıbbi-teknik donanımı, en az önemli görülen faktörün hastanenin tabelası, logosu ve renklerinin olduğunu; hastane seçiminde etkili olan faktörlerin de hizmet kalitesi, tanınırlık, personel, fiziki unsur ve tüketiciye maliyet şeklinde 5 boyutta toplandığ 1 tespit etmişlerdir.

Cerrahi operasyon geçiren kanser hastalarına yapılan araştırma (Prang, Canaway, Bismark, Dunt, Miller ve Kelaher, 2018, s.5) sonucunda, hastane tercihinde en etkili olan faktörlerin sırasıyla; uzmanlık (hastanenin sahip olduğu), eve yakınlık, hastane itibarı, geçmiş deneyimler, genel hekim önerileri, bekleme süresi, sağlık sigortası, aile/arkadaş çevresi, hastane hizmet bölgesi, hastanenin büyüklüğü ve web sayfaları olduğu tespit edilmiştir.

Diyarbakır'da yapılan araştırma (Kayaoğlu ve Gülmez, 2020, s.1267) sonucunda ise, özel hastane tercihinde; hizmet kalitesi, tecrübe ve başarı, maliyet, itibar, memnuniyet, erişim/ulaşım kolaylığ faktörlerinin etkili olduğu tespit edilmiştir.

\section{Hastane marka imaj1}

Marka tanımlarına bakıldığında; Kotler (2012)'in "ürün hattında yer alan bir ya da birden fazla öğenin, kaynağıyla ilgili özelliklerini belirlemek için kullanılan isim" olarak tanımladığı görülmektedir. Bir marka, rasyonel ve duygusal iki öğeden oluşur. Rasyonel öğe; markanın ne yaptığı, ne söylediği ve ne sunduğu ile ilgilenir. Rasyonel öğeler, marka iletişiminin temasını ve içeriğini, önerisini veya vaadini ortaya koyar. Duygusal öğeler ise; markanın kendisini nasıl ifade ettiği, anlattı̆̆ı ve sunduğu ile ilgilidir.

Sağlıkta başarılı bir markalaştırma stratejisi için göz önünde bulundurulması gereken unsurlar (Speak, 1996, s.40-42):

- Hastaların sağlık kuruluşları algılanmasını yeni bir gelecek odaklı stratejinin işaretini vererek yeniden şekillendirmek.

- Mevcut kimlikleri pekiştirip yeniden koordine etmek

- Anahtar sağlık hizmetleri kimlikleri ve yeni kimlikte güven ve eşitlik inşa etmek için bu varlıkları dengelemek ve bunları korumak

- Sağlık kuruluşunun değerlerini "markayı yaşama” yı güçlendirmek için kullanmak.

Kim vd. (2008: s.75) hastanelerde marka ederi kavramı üzerine bir çalışma yapmıştır. Bu çalışmada; başarılı müşteri ilişkileri yoluyla marka değeri yaratmayı etkileyen beş faktörü tanımlamaktadır: güven, müşteri memnuniyeti, ilişki taahhüdü, marka sadakati ve marka bilinirliği. Bu faktörler arasındaki ilişkilerin incelendiği araştırma sonucunda, hastanelerin müşteri ilişkilerini iyi yönetebiliyorlarsa imaj ve pozitif marka değeri yaratmada başarılı olabileceğini göstermektedir.

Hastane Marka İmajı kavramının Wu (2011: s.4873) tarafından kullanıldığı çalışmada; hizmet kalitesi, hasta memnuniyeti ve sadakat arasındaki ilişkiyi incelenmiştir. Araştırma sonucunda; hastane marka imajının hasta sadakatinde hem doğrudan hem de dolaylı etkilerinin olduğunu ortaya koyulmaktadır. Pozitif bir hastane marka imajının sadece hasta sadakatini doğrudan arttırmakla kalmayıp aynı zamanda algılanan hizmet kalitesini artırarak hasta memnuniyetini de arttırdığı ve dolayısıyla hastaların tekrar ziyaret etme niyetini artırdığını tespit etmiştir. Hastane marka imajı, hizmet kalitesini, hasta memnuniyetini ve hasta sadakatini arttırmada lider bir faktör olduğu belirtilmiştir.

\section{Araştırma yöntemi}

Araştırma süreci, “Amaç ve Önem”, “Kapsam ve Kısıtlar”, “Model ve Hipotezler”, “Süreç, Örneklem ve Ölçekler" ve "Analiz ve Bulgular" alt başlıkları ile değerlendirilmektedir.

\section{Araştırmanın amacı ve önemi}

Son yıllarda tüm dünyada kaliteli sağlık hizmeti sunabilmek adına devlet yatırımlarının yanında özel teşebbüslerin de arttığı gözlenmektedir. Ülkemizde de son yıllarda vatandaşların daha kaliteli hizmet alabilmelerini sağlamak adına gerek kamu yatırımları gerekse de özel yatırımlar hızla artmaktadır. 
Sağlık sektöründeki bu hızlı gelişme ile birlikte insanların sağlık hizmeti alabilecekleri alternatifler de artmıştır.

İnsanların ihtiyaçlarının çeşitlenmesi ve sağlık sektöründeki bu hızlı gelişmeler; tüketicilerin artan alternatifler arasından kendileri için en doğru olanı nasıl belirleyip seçtikleri konusu önemini ortaya çıkarmıştır. Bu alanda ilgili literatür incelendiğinde; çok fazla çalışmanın olmadığı görülmektedir. Bu çalışma çerçevesinde de; temel varsayımlar dikkate alınarak bir inceleme yapma yolu tercih edilmiştir. Buna göre; sağlık kuruluşu tercihinde bireysel, kurumsal ve çevresel etmenlerin bu tercih sürecindeki etkisi incelenmeye çalışılmıştır.

Literatür incelemesinde yer verdiğimiz konuların bir model çerçevesinde birlikte incelendiği bir çalışma ile karşılaşılmamıştır. Bu açıdan; yapılan bu çalışma alanda öncü nitelik taşımakta ve ilgili literatüre büyük katkı sağlayacağı düşünülmektedir. Bunun yanında, ortaya çıkacak sonuçlar öncül nitelikte ve geliştirmeye muhtaç durumda olmasına rağmen sektörel bakış açısının gelişmesine de büyük katkılar sunacağı düşünülmektedir. Bu değerlendirmelerin, ülke sağlık hizmeti kalitesinin geliştirilmesi ve beklenen sağlık turizmi hedeflerine ulaşılması konularında katkısının olacağı düşünülmektedir.

\section{Araştırmanın kapsamı ve kısıtları}

Sağlık kuruluşu tercihine etki eden etmenlerin incelenmesi için yapılan bu araştırmada çeşitli kısıtlar bulunmaktadır. Araştırmanın kısıtlarından ilki, örneklemi ile ilgilidir. Araştırmanın ana kütlesini İstanbul'da yaşayan ve sağlık kuruluşu tercihini kendi yapan tüm tüketiciler oluşturmaktadır. Ancak gerek zaman gerekse de maliyet kısıtlarından dolayı tüm tüketicilere ulaşma imkânı bulunamamaktadır. Bu yüzden örneklem yapısı gereği araştırma sonuçları genellenebilir nitelikte değildir.

Araştırma sürecinde karşılaşılan en büyük kısıtlardan biri de bu modelin daha önce test edilmemiş olmasıdır. Çalışma öncü niteliktedir. Modelin istatistiksel olarak anlamlı sonuçlar ortaya koyabileceği temel modeller çerçevesinde öngörülerek araştırma sürecine geçilmiştir.

Araştırmanın en önemli kısıtlarından biri de "genel poliklinik hizmeti" için hastane tercihi üzerine araştırmanın tasarlanmasıdır. Dolayısıyla aynı katılımcılar ile herhangi farklı bir birim için yapılacak araştırma farklı sonuçları ortaya koyabilecektir.

$\mathrm{Bu}$ kısıtlar nedeniyle çalışma sonucunda ulaşılan bulguların genellenebilir ve kesin sonuçlar mahiyetinde olmadığı kabul edilmektedir. Ancak yapılan çalışma öncü niteliğinde olduğu için gerek literatüre gerekse de sektöre önemli katkılar sunacak ve bu alanda yapılacak çalışmalara farklı bir yaklaşım kazandırabilecektir.

\section{Araştırma modeli ve hipotezler}

Araştırma modeli literatür taraması ile ortaya koyulup, uzmanlarla yapılan görüşmeler neticesine göre Şekil 1'de görüldüğü gibi düzenlenmiştir. Önerilen bu modelde üç bağımsız bir bağımlı yapıyı içeren, toplamda dört ölçek yer almaktadır. Bu modele göre; "Sağlıklı Yaşam Biçimi Davranışı", "Kurumsal ve Çevresel Etmenler" ile "Hastane Marka İmajı", "Hastane Tercihi"ni etkilemektedir. Buna bağlı olarak araştırmanın temel ve alt hipotezleri aşağıda belirtilmiştir:

H1: Sağlıklı yaşam biçimi davranışı, hastane tercihini etkiler.

H1a: Kendini gerçekleştirme, hastane tercihini etkiler.

H1b: Sağlık sorumluluğu, hastane tercihini etkiler.

H1c: Egzersiz, hastane tercihini etkiler.

H1d: Beslenme, hastane tercihini etkiler.

H1e: Kişilerarası destek, hastane tercihini etkiler.

H1f: Stres yönetimi, hastane tercihini etkiler.

H2: Kurumsal ve çevresel etmenler, hastane tercihini etkiler.

H2a: Kalite ve nezaket, hastane tercihini etkiler. 
H2b: Süreç, hastane tercihini etkiler.

H2c: İtibar, hastane tercihini etkiler.

H2d: Ulaşabilirlik, hastane tercihini etkiler.

H2e: Fiziksel koşul, hastane tercihini etkiler.

H3: Hastane marka imajı, hastane tercihini etkiler.

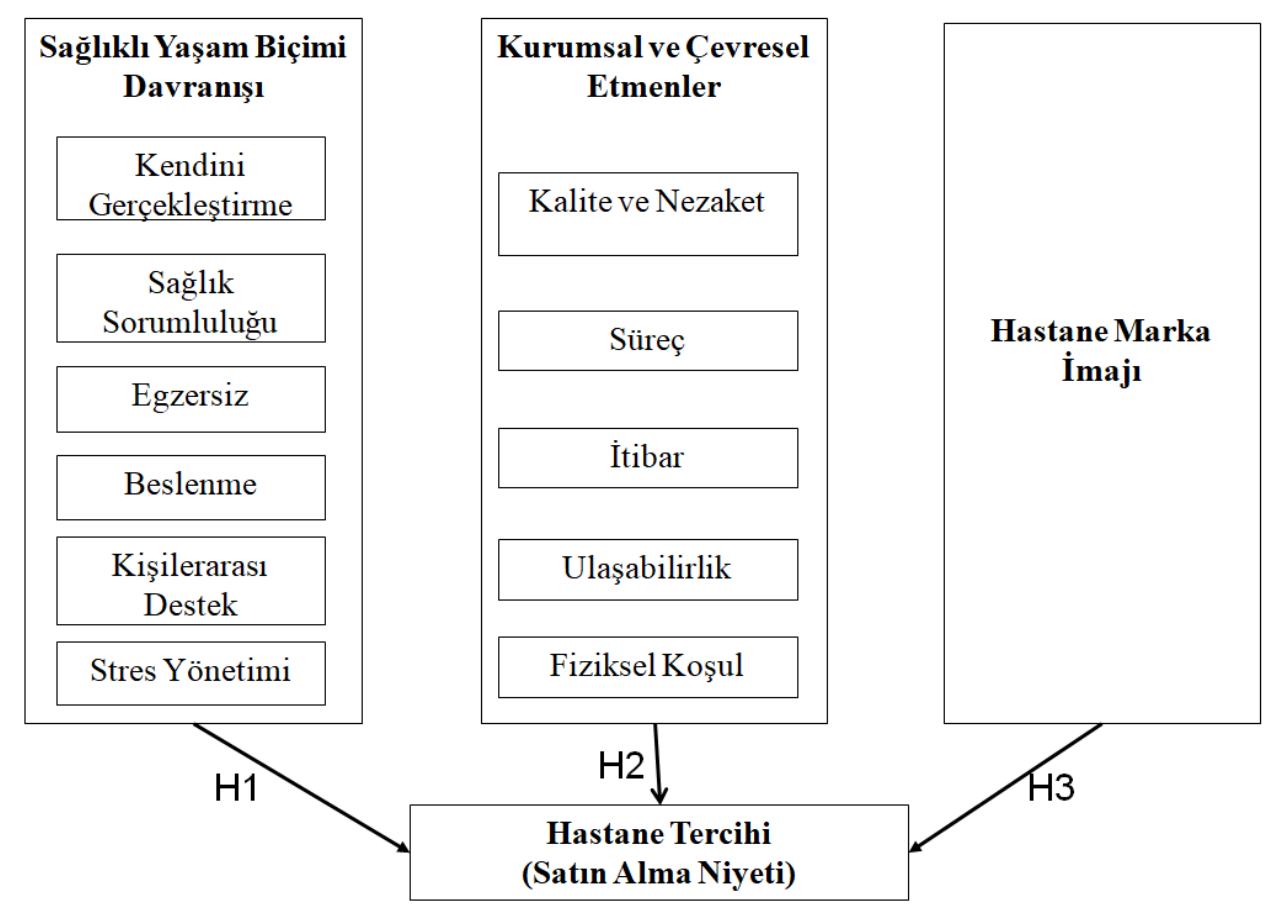

Şekil 1: Araştırma Modeli

Kaynak: Yazar tarafından üretilmiştir.

\section{Süreç, örneklem ve ölçekler}

Araştırmanın öncü niteliğinden dolayı; kantitatif aşamasına geçilmeden önce, elde edilen ölçeklerin Türkiye özelinde uygulanabilirliği ile oluşturulan model ve ölçeklerin doğruluğu konusunda kalitatif bir çalışma gerekliliği oluşmuştur. Bundan dolayı uzmanlarla görüșme yapılmasına karar verilmiştir. Uzmanların belirlenmesinde konunun kapsamına da uygun olarak, özellikle sağlık davranışı konusunun psikolojik altyapısı da göz önünde bulundurulup bu alanda çalışmaları olan akademisyenler tercih edilmiştir. Bunun yanında gerek kamunun ilgili kurumlarındaki deneyimi gerekse de sağlık sektöründe özel teşebbüslerin faaliyetleri içindeki görevlerinden dolayı, bilgi birikiminden istifade edebilmek amacıyla bu uzmanlar tercih edilmiştir. Görüşmeler neticesinde; oluşturulan modelin uygunluğu konusunda hem fikir olunmuş, kullanılacak ölçeklerin Türkiye'ye uygun şekline karar verilmiştir. Bunun yanında özellikle kurumsal ve çevresel etmenler ölçeğine Türkiye koşulları göz önünde bulundurularak eklemeler yapılmıştır.

Ölçeklerin belirlenmesi ve yapılan uzmanlarla görüşme neticesinde anket formu oluşturularak, konu ile ilgili kişiler tercih edilerek anket uygulamasında pilot çalıșma gerçekleştirilmiştir. Bu çalışmanın amacı ankette yer alan değişkenlerin ifadelerinin doğru anlaşılıp anlaşılmadığının test edilmesidir. Yapılan bu çalışma neticesine göre anket formunda ortaya çıkan gerekli düzenlemeler yapılmış ve anket formunun nihai hali verilmiştir.

Anketin uygulanma sürecinde veri toplama yöntemlerinden yüz yüze anket yöntemi kullanılmıştır. Araştırmanın hedef kitlesini İstanbul'da yaşayan ve sağlık kuruluşu tercihini kendi yapan kişiler oluşturmaktadır. Bu süreçte örnekleme yöntemlerinden kolayda örnekleme yöntemi tercih edilmiştir. 
Örneklem büyüklüğü hesaplanırken \%5 hata payı ve \%95 güven aralığında, en yaygın kullanılan örnekleme formülü (Kurtuluş, 2010: 67) yardımı ile 384 rakamına ulaşılmaya çalışılmıştır. Anket, 2019 Kasım - 2020 Şubat arasında uygulanmıştır. Sürecin sonucunda toplamda 657 ankete ulaşılmış, bunlardan 628 adedinin kullanılabilir nitelikte olduğu tespit edilmiştir. Veri toplama süreci 2020 yılından önce başladığı için anket çalışmalarında dönem itibariyle gerekmediğinden etik kurula başvurulmamıştır.

Sağlıklı Yaşam Davranışı Ölçeği toplam 6 boyutta 48 maddeden oluşan bir ölçektir. Ölçek Walker vd. (1987) tarafından ortaya konmuş ve Walker ve Hill-Polerecky (1996) tarafından revize edilmiştir. Uzmanlarla yapılan görüşmeler sonucunda ölçeğin ilk halinin Türkiye'de kullanımın daha uygun olacağı belirlenmiştir. Esin (1997)'de Türkçe olarak kullanılan ölçeğin çevirisi tercih edilmiştir. Kurumsal ve Çevresel Etmenler Ölçeği toplam beş boyutta 29 maddeden oluşan bir ölçektir. Temel olarak Lee, Shih ve Chung (2008)'un geliştirdiği 19 değişkenli ölçek alınmış, bu ölçeğe uzmanlarla yapılan görüşmelerden elde edilen 10 madde daha eklenerek düzenlenmiştir. Hastane Marka İmajı Ölçeği tek boyutta toplam 6 maddeden oluşan bir ölçektir. Ölçek Wu (2011) tarafından geliştirilmiştir. Sağlık kuruluşu tercihi ölçeği olarak tek boyutta 4 maddeden oluşan satın alma niyeti ölçeği kullanılmıştır. Ölçek, Coyle ve Thorson (2001) tarafından geliştirilmiştir.

Tercih edilen bu ölçeklerin anket uygulaması yapılmadan önce, uzmanlarla görüşme ile uygunluğu değerlendirilmiş, sonrasında yapılan pilot çalışma ile de güvenilirliği test edilerek anket uygulama sürecine geçilmiştir. Pilot uygulamada Cronbach alfa katsayıları; Sağlıklı Yaşam Davranışı ölçeği için 0,857; Kurumsal ve Çevresel Etmenler İçin 0,823; Hastane Marka İmajı için 0,872 ve Hastane Tercihi İçin 0,884 olduğu görülmüştür. Nihai uygulama sonucunda ölçeklerin güvenilirlik değerlerine ve faktör yüklerine aşağıda yer verilmektedir.

\section{Analiz ve bulgular}

Araştırmanın analiz kısmında IBM SPSS Statistics 20 ve AMOS 22 programları kullanılmıştır. Çalışmada marka imajı ölçeği kullanıldığı için araştırmaya katılanların daha önce hizmet aldığı özel hastanelerden hangisini en fazla tercih ettiği sorulmuş ve alınan cevaplara göre 628 katılımcının 243'ü AC hastanelerini $224^{\prime} \ddot{u}$ ise MP hastanelerini tercih ettiğini belirtmiştir, bunun sebebinin ise; araştırmanın yapıldığı dönemde İstanbul'da en fazla hastane şubesi olan bu markaların olması söylenebilir.

Demografik özelliklere bakıldığında, katılımcıların;

o $\% 48,9$ oranla 307 'si kadın, $\% 51,1$ oranla 321 erkektir.

o \%25,2 oranla 158'i 18-25 yaş aralığında, \%32 oranla 201'i 26-33 yaş aralığında, \%22,6 oranla 142'si 34-41 yaş aralığında ve \%19 oranla 119 'u 42 yaş ve üzerindedir.

o \%46,2 oranla 290 ' 1 bekar, $\% 40,3$ oranla $253^{\prime}$ ü evli ve çocukludur.

o Genel durumda \%43,5 oranla 273'ü; AC hastanelerini tercih edenlerde $\% 40,7$ oranla $99^{\prime}$ u ve MP hastaneleri tercih edenlerin \%46 oranla 103'ü Lisans seviyesinde eğitim almışlardır.

o Genel durumda \%57,6 oranla 362'sinin; AC hastanelerini tercih edenlerde \%69,1 oranla 168 'inin ve MP hastanelerini tercih edenlerin \%63,8 oranla 143'ünün Özel Sektör Çalışanı olduğu tespit edilmiştir.

Araştırmada kullanılan ölçeklerin güvenilirliği SPSS programı aracılığıyla güvenilirlik analizi ile incelenmiştir. Faktör analizi sonrasında ise her bir faktörün güvenirliliğinin test edilmesi gerekmektedir (Durmuş vd, 2013: 89). Güvenilirlik analizinde Cronbach alfa katsayılarından yararlanılmıştır. Kurtuluş'a göre (2010: 184); Cronbach alfa katsayısı keşfedici araştırma modelleri haricinde, 0,70'ten büyük olmalıdır. Aşağıdaki tabloda güvenilirlik analizi sonucunda elde edilen güvenilirlik yüzdeleri yer almaktadır.

Tablo 1'e göre faktörlerin çoğunun yukarıda belirtilen 0,70 güvenilirliğin üzerinde olduğu görülmektedir. Kalaycı'ya (2005: 405) göre; Cronbach alfa katsayısı 0,60 ila 0,80 arasında ise; ölçek oldukça güvenilir, 0.80 ila 1.00 aralığında ise yüksek derecede güvenilir kabul edilmektedir. Bu bilgiden hareketle, ölçeklerin güvenilirlik seviyelerinin "oldukça güvenilir" veya "oldukça güvenilir" olduğu söylenebilmektedir. 
Tablo 1: Araştırmada Yer Alan Faktörlerin Güvenilirlik Tablosu

\begin{tabular}{|c|c|c|c|c|}
\hline & Değişken Sayısı & Genel & $\mathrm{AC}$ & MP \\
\hline Sağlıklı Yaşam Davranışı & 48 & 0,932 & 0,925 & 0,914 \\
\hline Kendini Gerçekleştirme & 13 & 0,876 & 0,88 & 0,841 \\
\hline Sağlık Sorumluluğu & 10 & 0,847 & 0,859 & 0,862 \\
\hline Egzersiz & 5 & 0,772 & 0,804 & 0,735 \\
\hline Beslenme & 6 & 0,744 & 0,727 & 0,692 \\
\hline Kişilerarası Destek & 7 & 0,717 & 0,69 & 0,677 \\
\hline Stres Yönetimi & 7 & 0,731 & 0,697 & 0,738 \\
\hline Kurumsal ve Çevresel Etmenler & 24 & 0,893 & 0,868 & 0,914 \\
\hline Kalite ve Nezaket & 8 & 0,875 & 0,826 & 0,886 \\
\hline Süreç & 5 & 0,883 & 0,864 & 0,86 \\
\hline İtibar & 5 & 0,729 & 0,687 & 0,709 \\
\hline Ulaşılabilirlik & 4 & 0,77 & 0,753 & 0,726 \\
\hline Fiziksel Koşul & 2 & 0,787 & 0,751 & 0,797 \\
\hline Hastane Marka İmajı & 6 & 0,902 & 0,835 & 0,92 \\
\hline Hastane Tercihi & 4 & 0,942 & 0,926 & 0,951 \\
\hline
\end{tabular}

Kaynak: Yazar tarafından üretilmiştir.

Çalışma çerçevesinde kullanılan ölçeklere Keşfedici ve Doğrulayıcı faktör analizleri uygulanmıştır. Yapılan faktör analizleri sonucunda "Sağlıklı Yaşam Davranışı", "Hastane Marka İmajı" ve "Hastane Tercihi" ölçeklerinin kabul edilebilir uyum değerleri olduğu tespit edilmiştir. "Kurumsal ve Çevresel Etmenler" ölçeğine yönelik yapılan doğrulayıcı faktör analizi sonucuna göre bazı değişkenler çıkarılarak iyileştirmeler yapılmıştır. Bu iyileştirmelerde ilk olarak faktör analizinden çıkarıldığında ölçek güvenilirliğini yükselten değişiklikler tespit edilerek çıkarılmış daha sonrasında ise toplam faktör açılayıcılığı göz önünde bulundurulmuştur, buna göre çıkarılan değişkenler; hastanenin çevresi, her brançta hizmet verme, özel oda imkânı, kolay otopark ve doktoru bekleme süresidir.

En başta ortaya konulan model, faktör analizleri ile düzenlenen ölçekler kullanılarak yol analizi yardımı ile test edilmiştir. Bu çerçevede; yol analizi tüm verinin olduğu veri setinde, AC veri setinde ve MP setinde ayrı ayrı bakılarak model AMOS 22 programı ile üç kere test edilmiş üç farklı revize edilmiş modele ulaşılmıştır. 


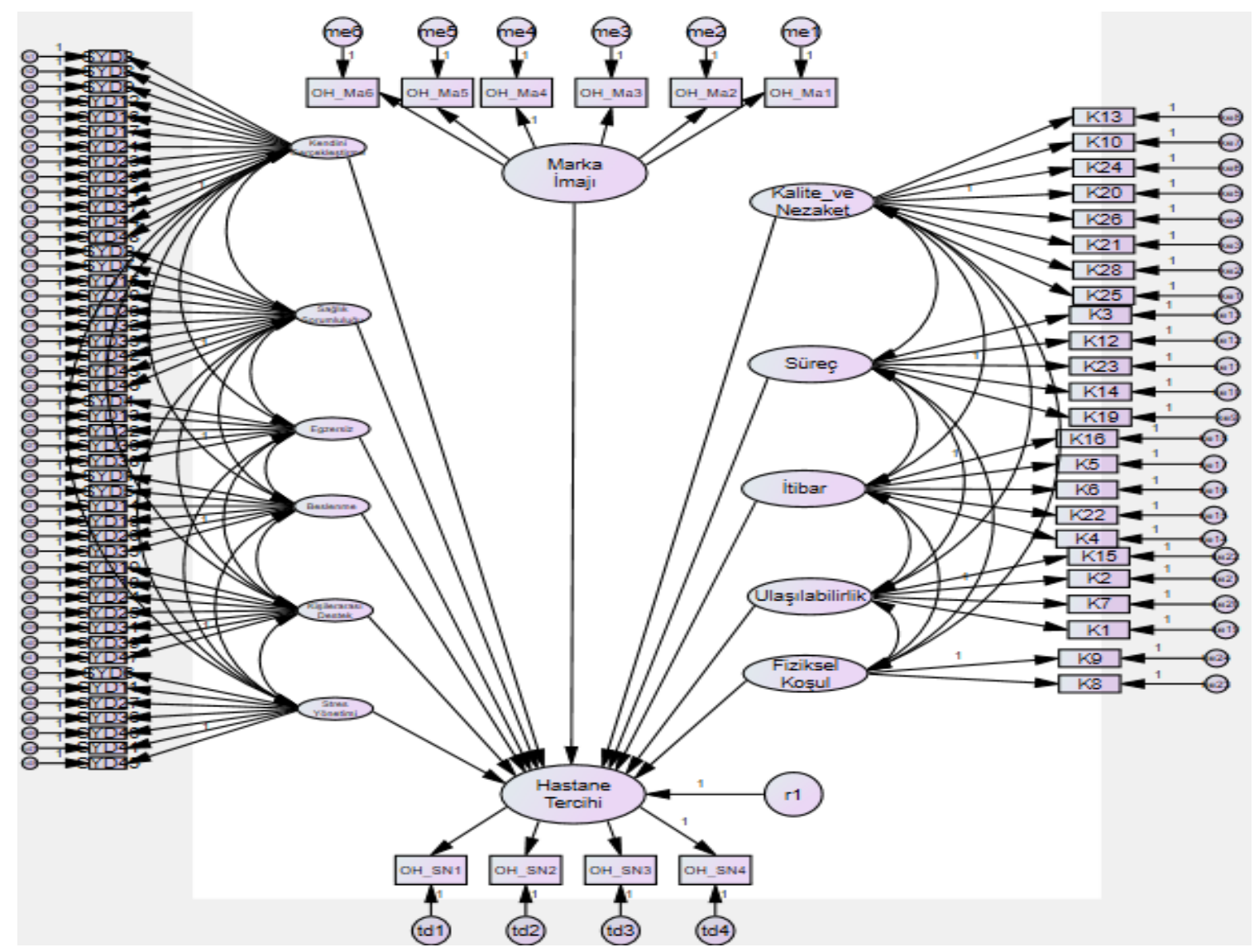

Şekil 2: Yapısal Eşitlik Modeli ile Yol Analizi Kullanılarak Önerilen Modelin Hipotezlerinin Testi

Kaynak: Yazar tarafından üretilmiştir.

Uyum değerlerine bakılarak yapılan değerlendirmeler çerçevesinde, çalışma başında belirtilen hipotezlerin kabul/red durumları Tablo 2' de yer almaktadır.

Tablo 2'ye göre; H3 revize edilmiş tüm modellerde kabul edilmiştir. H1 ve H2'nin alt hipotezlerle test edildiği çalışmada, kabul ve red durumlarında modellerde farklılaşmalar bulunmaktadır. Tüm modellerde ortak olarak; H1b hipotezi kabul edilirken; H1c, H2c ve H2e hipotezi tüm modellerde reddedilmiştir.

Tüm veri için yapılan yol analizi sonucunda revize edilmiş model ve bu modelde yer alan etki değerlerine göre; Kurumsal ve Çevresel etmenlerinin tamamında, Sağlıklı Yaşam Biçimi Davranışı ölçeğinin ise "Kendini Gerçekleştirme", "Egzersiz" ve "Beslenme" faktörlerinin hastane tercihine anlamlı etkisinin olmadığı tespit edilmiştir. Buna karşılık; “Marka İmajı” ölçeğinin 0,69 katsayısı ile, "Stres Yönetimi" faktörünün ise 0,36 katsayısı ile hastane tercihine 0,05 güven aralığında anlamlı olumlu etki ettiği tespit edilmiştir. "Kişilerarası Destek" faktörünün -0,28 katsayısı ile, "Sağlık Sorumluluğu" faktörünün ise $-0,15$ katsayısı ile hastane tercihine 0,05 güven aralığında anlamlı ters yönlü etki ettiği tespit edilmiştir. 
Tablo 2: Hipotez Testi Kabul / Red Tablosu

\begin{tabular}{|c|c|c|c|}
\hline HIPOTEZLER & TÜM VERİ & $\mathrm{AC}$ & MP \\
\hline H1: Sağlıklı Yaşam Biçimi Davranışı, Hastane Tercihini Etkiler. & $\begin{array}{l}\text { KISMEN } \\
\text { KABUL }\end{array}$ & KISMEN KABUL & KISMEN KABUL \\
\hline H1a: Kendini Gerçekleştirme, Sağlık Kuruluşu Tercihini Etkiler. & RED & RED & KABUL \\
\hline H1b: Sağlık Sorumluluğu, Hastane Tercihini Etkiler. & KABUL & KABUL & KABUL \\
\hline H1c: Egzersiz, Hastane Tercihini Etkiler. & RED & RED & RED \\
\hline H1d: Beslenme, Hastane Tercihini Etkiler. & RED & KABUL & RED \\
\hline H1e: Kişilerarası Destek, Hastane Tercihini Etkiler. & KABUL & KABUL & RED \\
\hline H1f: Stres Yönetimi, Hastane Tercihini Etkiler. & KABUL & RED & KABUL \\
\hline H2: Kurumsal ve Çevresel Etmenler, Hastane Tercihini Etkiler. & RED & KISMEN KABUL & KISMEN KABUL \\
\hline H2a: Kalite ve Nezaket, Hastane Tercihini Etkiler. & RED & RED & KABUL \\
\hline H2b: Süreç, Hastane Tercihini Etkiler. & RED & KABUL & RED \\
\hline H2c: İtibar, Hastane Tercihini Etkiler. & RED & RED & RED \\
\hline H2d: Ulaşabilirlik, Hastane Tercihini Etkiler. & RED & KABUL & KABUL \\
\hline H2e: Fiziksel Koşul, Hastane Tercihini Etkiler. & RED & RED & RED \\
\hline H3: Hastane Marka İmajı, Hastane Tercihini Etkiler. & KABUL & KABUL & KABUL \\
\hline
\end{tabular}

Kaynak: Yazar tarafından üretilmiştir.

AC hastanesi özelinde yapılan yol analizi sonucunda revize edilmiş model ve bu modelde yer alan etki değerlerine göre; "Kurumsal ve Çevresel Etmenler" ölçeğinin "Kalite ve Nezaket", "İtibar" ve "Fiziksel Koşul" faktörlerinde; "Sağlıklı Yaşam Biçimi Davranışı" ölçeğinin ise "Kendini Gerçekleştirme", "Egzersiz" ve "Stres Yönetimi" faktörlerinin hastane tercihine anlamlı etkisinin olmadığ1 tespit edilmiştir. Buna karşılık; "Marka İmajı" ölçeğinin 0,58 katsayısı ile, "Sağlıklı Yaşam Biçimi Davranışı" ölçeğinin "Beslenme" faktörünün 0,24 katsayısı ile, "Kişilerarası Destek" faktörünün 0,12 katsayısı ile; "Kurumsal ve Çevresel Etmenler" ölçeğinin "Süreç" faktörünün 0,16 katsayısı ile hastane tercihine 0,05 güven aralığında anlamlı olumlu etki ettiği tespit edilmiştir. "Sağlıklı Yaşam Biçimi Davranışı" ölçeğinin "Sağlık Sorumluluğu" faktörünün -0,34 katsayısı ile, "Kurumsal ve Çevresel Etmenler" ölçeğinin "Ulaşılabilirlik" faktörünün ise -0,17 katsayısı ile hastane tercihine 0,05 güven aralığında anlamlı ters yönlü etki ettiği tespit edilmiştir.

MP hastanesi özelinde yapılan yol analizi sonucunda revize edilmiş model ve bu modelde yer alan etki değerlere göre ise; "Kurumsal ve Çevresel Etmenler" ölçeğinin "Süreç", "İtibar" ve "Fiziksel Koşul" faktörlerinde; "Sağlıklı Yaşam Biçimi Davranışı" ölçeğinin "Egzersiz", "Beslenme", ve "Kişilerarası Destek" faktörlerinin hastane tercihine anlamlı etkisinin olmadığı tespit edilmiştir. Buna karşılık; "Marka İmajı" ölçeğinin 0,76 katsayısı ile, "Sağlıklı Yaşam Biçimi Davranışı" ölçeğinin "Stres Yönetimi" faktörünün 0,72 katsayısı ile; "Kurumsal ve Çevresel Etmenler" ölçeğinin "Ulaşılabilirlik" faktörünün 0,19 katsayısı ile hastane tercihine 0,05 güven aralığında anlamlı olumlu etki ettiği tespit edilmiştir. "Sağlıklı Yaşam Biçimi Davranışı" ölçeğinin "Kendini Gerçekleştirme" faktörünün -0,45 katsayısı ile, "Sağlık Sorumluluğu" faktörünün -0,27 katsayısı ile, "Kurumsal ve Çevresel Etmenler" ölçeğinin "Kalite ve Nezaket" faktörünün ise -0,18 katsayısı ile hastane tercihine 0,05 güven aralığında anlamlı ters yönlü etki ettiği tespit edilmiştir.

\section{Sonuç}

Araştırma çerçevesinde yapılan analizler sonucunda elde edilen bulgulara göre; oluşturulan hipotezlerin bazıları kabul edilirken bazılarının reddedildiği görülmektedir. Burada dikkat çeken nokta, tüm analizlerde; “Hastane Marka İmajı"nın "Hastane Tercihi”ni olumlu yönde etkilediği görülmektedir. Bu da hastane yönetimlerine, marka konusunda yaptıkları çalışmaların müşterileri tarafından ne kadar olumlu karşılandığını göstermektedir.

Literatür incelemesinde de yer verildiği üzere ve araştırmanın tasarlanmasında da bahsedildiği üzere; hastane tercihine etki eden etmenler konusunda literatürde yer alan çalışmalar, bu çalışmada Kurumsal ve Çevresel etmenler başlığı altında yer aldığı şekilde incelenmiştir. Toplu olarak özellikle 
sağlık davranışı kavramının dahil edilerek, bireylerin sağlıklı yaşama nasıl yaklaştıklarını tespit ederek, hastane tercihine etkisinin incelenmesi adına öncü niteliktedir.

Ölçek bazlı bakıldığında; Sağlıklı Yaşam Davranışı (Esin, 1997), Hastane Marka İmajı (Wu, 2011) ve Hastane Tercihi (Coyle ve Thorson, 2001) ile ilgili elde edilen bulgular literatürdeki ile benzer sonuçlara ulaşılmıştır. Ancak Kurumsal ve Çevresel Faktörler için temel olarak tercih edilen çalışmada Lee, Shih ve Chung (2008)'un geliştirdiği 19 değişkenli ölçekte sonuçlar sırasıyla "uygunluk ve ekonomiklilik", "itibar ve ayrıcalık", "kalite ve nezaket" ve "zamandalık (timeliness)" temel 4 faktörde ortaya konmuşken; bu çalışmada sırasıyla, "Kalite ve Nezaket", "Süreç", "İtibar", "Ulaşılabilirlik" ve "Fiziksel Koşul" faktörleri tespit edilmiştir. Literatürde farklı çalışmalarda da (Tüfekci ve Asığbulmuş, 2016; Şantaş, Kurşun ve Kar, 2016; Kayaoğlu ve Gülmez, 2020) bunlara benzer faktörlerin olduğu görülmektedir.

Sağlıklı Yaşam Davranışı' nın Hastane Tercihi'ne etkisi açısından bakıldığında; tüm veri grupları için "Sağlık Sorumluluğu"nun negatif yönlü etkisi olduğu görülmektedir. Bu bulguya göre, sağlık sorumluluğu artanların hastane tercihlerinde kesin kararlı olmadıkları, tercihlerini sürekli değiştirip, farklı alternatifleri deneme eğiliminde oldukları söylenebilmektedir. AC hastanesini tercih edenlerde “Kişilerarası Destek"in Hastane Tercihi'ni olumlu yönde etkilediği tespit edilmiştir. Bu bulgu ise; AC hastanesinde hizmet alanların çevresinden aldığ 1 destek ile bu hastaneyi tercih etmeye devam ettiklerini, bu hastaneden hizmet almanın sosyal çevreden kabul gördüğünü göstermektedir. MP hastanesini tercih edenlerde ise; "Kendini Gerçekleştirme"nin Hastane Tercihi'ni negatif yönde etkilediği görülmektedir. Bu anlamda bakıldığında; MP hastanesini tercih eden örneklemde öz yeterlik arttıkça tercihlerini değiştirme eğilimi artmaktadır; bunun da kişilerin farklı alternatifleri de değerlendirmek istediklerini gösterdiği söylenebilmektedir. Bunun yanında, yine MP hastanesini tercih edenlerde; "Stres Yönetimi"nin Hastane Tercihi'ni olumlu etkilediği görülmektedir; stresini kontrol edebilen katılımcıların aynı tercihte bulunmaya devam edeceklerini göstermektedir.

Kurumsal ve Çevresel Etmenler'in Hastane Tercihi'ne etkisi açısından bakıldığında; AC hastanesini tercih edenlerin hizmet aldıkları süreçten duydukları memnuniyetin tercihlerini olumlu yönde etkilediği, ulaşılabilirliğin ise olumsuz etkilediği tespit edilmiştir. Bundan hareketle, AC hastanesinin ulaşılabilirlik konusunda yeni düzenlemelere ihtiyaç duyduğu söylenebilmektedir. MP hastanesini tercih edenlerde ise; hastanenin kolay ulaşılabilir olmasının tercih edilmesinde olumlu etkisinin olduğu, süreç içerisinde personel davranışlarının ise olumsuz etkisinin olduğu tespit edilmiştir. Bu bulgudan hareketle, MP hastanesi personelin müşterilerine davranış şekilleri ile ilgili çalışma yapmasının yararlı olabileceği belirtilebilir.

Yapılan bu çalışma hastane tercihine etki eden etmenlerin araştırılması konusunda literatürde var olan en kapsamlı çalışmalardan biri niteliğindedir. Bu anlamda literatüre önemli bir katkı sunmaktadır. Burada kullanılan ölçeklerin her birinin uyumlaştırılmasının, süreçte etkili olabilecek diğer kavramların eklenmesinin, hastane hizmet süreçlerinde var olan diğer birimleri de kapsayacak şekilde daha kapsamlı çalışmaların yapılmasının hem literatüre hem de sektöre önemli katkılar sunacağı düşünülmektedir. Bu çalışma kapsamında veriler pandemi döneminden önce toplanmıştır, yaşanan bu sürecin sağlık konusundaki algıları değiştirebileceği öngörülebilmektedir. Bu yüzden bu çalışmanın pandemi sürecinde veya sonrasında uygulanması ile değişim gözlemlenebilecektir.

\section{Hakem Değerlendirmesi / Peer-review:}

Dış bağımsız

\section{Externally peer-reviewed}

\section{Çıkar Çatışması / Conflict of interests:}

Yazar(lar) çıkar çatışması bildirmemiştir.

The author(s) has (have) no conflict of interest to declare.

\section{Finansal Destek / Grant Support:}

Yazar bu çalışma için finansal destek almadığını beyan etmiştir.

The author declared that this study has received no financial support. 


\section{Kaynakça / References}

Abelin, T., Brzezinski, Z. J., Carstairs, V. D., \& World Health Organization. (1987). Measurement in health promotion and protection. World Health Organization. Regional Office for Europe.

Ajzen, I. (1991). The theory of planned behavior. Organizational behavior and human decision processes, 50(2), 179-211.

Ayhan, B., \& Canöz, K. (2006). Hastaların Hastane Tercihinde Etkili Olan Halkla İlişkiler Faaliyetleri. II. Ulusal Halkla İlişkiler Sempozyumu, Kocaeli Üniversitesi, 27-28.

Bahar, Z., Beşer, A., Gördes, N., Ersin, F., \& Kıssal, A. (2008). Sağlıklı yaşam biçimi davranışları ölçeği II'nin geçerlik ve güvenirlik çalışması. Cumhuriyet Üniversitesi Hemşirelik Yüksekokulu Dergisi, 12(1), 1-13.

Boscarino, J., \& Stelber, S. R. (1982). Hospital shopping and consumer choice. Journal of Health Care Marketing, 2(2), 15-23.

Conner, M., \& Norman, P. (2005). Predicting health behaviour. McGraw-Hill Education (UK).

Coyle, J. R., \& Thorson, E. (2001). The effects of progressive levels of interactivity and vividness in web marketing sites. Journal of advertising, 30(3), 65-77.

Deci, E. L., \& Ryan, R. M. (1985). The general causality orientations scale: Self-determination in personality. Journal of research in personality, 19(2), 109-134.

Deci, E. L., \& Ryan, R. M. (2000). The" what" and" why" of goal pursuits: Human needs and the selfdetermination of behavior. Psychological inquiry, 11(4), 227-268.

Durmuş, B., Yurtkoru, E.S., \& Çinko, M. (2013). Sosyal Bilimlerde SPSS’le Veri Analizi. Bata Basım A.Ş. (İstanbul-Türkiye).5. Baskı.

Dünya Sağlık Örgütü (DSÖ / WHO) (2018) Erişim Adresi: https://www.who.int/

Esin, M.N., (1997). “Endüstriyel Alanda Çalışan İşçilerin Sağlık Davranışlarının Saptanması ve Geliştirilmesi". İstanbul Üniversitesi, Sağlık B. Enstitüsü, Hemşirelik/Halk Sağllğı Hemşireliği, Yayınlanmış Doktora Tezi.

Fertman C.I. ve Allensworth, D.D. (2010). Health Promotion Programs: From Theory To Proctice. Jossey-Bass, San Francisco.

Fishbein, M., \& Ajzen, I. (1975). Belief, Attitude, Intention, and Behavior: An Introduction to Theory and Research. Addison Wesley Publishing Company.

Glanz, K., Rimer, B. K., \& Viswanath, K. (Eds.). (2008). Health behavior and health education: theory, research, and practice. John Wiley \& Sons.

Kalaycı, Ş. (2010). SPSS uygulamalı çok değişkenli istatistik teknikleri. Ankara, Turkey: Asil Yayın Dağıtım.

Kavuncubaşı, S. (2000): Hastane ve Sağlık Kurumları Yönetimi, Ankara: Siyasal Kitabevi.

Kayaoğlu, A. ve Gülmez, Y. S. (2020). Sağlık Hizmetleri Tüketicisi Olarak Hastaların Özel Hastane Tercihini Etkileyen Faktörlerin Belirlenmesi: Diyarbakır Örneği. Atatürk Üniversitesi İktisadi ve İdari Bilimler Dergisi, 34(4), 1267-1286.

Kim, K. H., Kim, K. S., Kim, D. Y., Kim, J. H., \& Kang, S. H. (2008). Brand equity in hospital marketing. Journal of business research, 1(61), 75-82.

Kotler P.: Marketing Management. 14. Edition, Printice Hall, New York, 2012.

Kurtuluş, K. (2010). Araştırma yöntemleri. Türkmen Kitabevi.

Lane, P. M., \& Lindquist, J. D. (1988). Hospital Choice: A Summary Of The Key Empirical And Hypothe. Marketing Health Services, 8(4), 5-20.

Lee, W. I., Shih, B. Y., \& Chung, Y. S. (2008). The exploration of consumers' behavior in choosing hospital by the application of neural network. Expert systems with applications, 34(2), 806-816. 
Madden, T. J., Ellen, P. S., \& Ajzen, I. (1992). A comparison of the theory of planned behavior and the theory of reasoned action. Personality and social psychology Bulletin, 18(1), 3-9.

Öztürk, M. (2000): Çağdaş Hastane Yöneticiliği Sorunlar ve Yaklaşımlar, İstanbul: MTM Yayın No:6.

Parkerson Jr, G. R., Connis, R. T., Broadhead, W. E., Patrick, D. L., Taylor, T. R., \& Tse, C. K. J. (1993). Disease-specific versus generic measurement of health-related quality of life in insulin-dependent diabetic patients. Medical care, 629-639.

Pender, N. J. (2011). Health promotion model manual. University of Michigan. Deep Blue. https://deepblue.lib.umich.edu/handle/2027.42/85350

Pender,N., Murdaugh C., ve Parsons M.A..(2015): Health promotion in Nursing Practice. Pearson, Seventh Ed., New Jersey.

Prang, K. H., Canaway, R., Bismark, M., Dunt, D., Miller, J. A., \& Kelaher, M. (2018). Public performance reporting and hospital choice: a cross-sectional study of patients undergoing cancer surgery in the Australian private healthcare sector. BMJ open, 8(4), e020644.

Prochaska, J. O., \& DiClemente, C. C. (1982). Transtheoretical therapy: toward a more integrative model of change. Psychotherapy: theory, research \& practice, 19(3), 276.

Rogers, R. W. (1975). A protection motivation theory of fear appeals and attitude change1. The journal of psychology, 91(1), 93-114.

Rosenstock,I.M.(1974).Historical origins of the health belief model.Health education monographs, 2(4), 328-335.

Ross, C. K., Steward, C. A., \& Sinacore, J. M. (1993). The importance of patient preferences in the measurement of health care satisfaction. Medical care, 1138-1149.

Rotter, R.B. (1966) Generalized expectancies for internal and external control of reinforcement, Psychological Monographs: General and Applied, 80 (whole no. 609), 1-28.

Schwarzer, R., Sniehotta, F. F., Lippke, S., Luszczynska, A., Scholz, U., Schüz, B., Wegner, M., \& Ziegelmann, J. P. (2003). On the assessment and analysis of variables in the health action process approach: Conducting an investigation.Berlin: Freie Universeitat Berlin.

Schwarzer, R. (2008). Modeling health behavior change: How to predict and modify the adoption and maintenance of health behaviors. Applied psychology, 57(1), 1-29.

Speak, K. D. (1996). The challenge of health care branding. Marketing Health Services, 16(4), 40-42.

Şantaş, F., Kurşun, A., \& Ahmet, K. A. R. (2016). Hastane tercihine etki eden faktörler: Sağlik hizmetleri pazarlaması perspektifinden alan araştırması. Hacettepe Sağlık İdaresi Dergisi, 19(1), 1733.

Tüfekçi, N., \& Asığbulmuş, H. (2016). The factors that effective in the choice of hospital and patient satisfaction: the sample of Isparta. Journal of Current Researches on Health Sector, 6(2), 71-92.

Walker SN, Sechrist KR \& Pender NJ (1987) The Health Promoting Lifestyle Profile development and psychometric characteristics. Nursing Research, 36(2): 76-80.

Walker, S. N., \& Hill-Polrecky, D. (1996). Psychometric evaluation of the Health-Promoting Lifestyle Profile II. Proceedings of the 1996 Scientific Session of the American Nurses Association's Council of Nurse Researchers, June 13-14, Washington, DC.

Wallston, B. S., Wallston, K. A., Kaplan, G. D., \& Maides, S. A. (1976). Development and validation of the health locus of control (HLC) scale. Journal of consulting and clinical psychology, 44(4), 580.

Wallston, K. A., Smith, R. A., King, J. E., Forsberg, P. R., Wallston, B. S., \& Nagy, V. T. (1983). Expectancies about Control Over Health. Relationship to Desire for Control of Health Care. Personality and Social Psychology Bulletin, 9(3), 377-385.

Wallston, K.E. (1992) Hocus-pocus, the focus isn't strictly locus: Rotter's social learning theory modified for health, Cognitive Therapy and Research, 16, 183- 99. 
Weinstein, N. D. (1980). Unrealistic optimism about future life events. Journal of personality and social psychology, 39(5), 806-820.

Wu, C. C. (2011). The impact of hospital brand image on service quality, patient satisfaction and loyalty. African Journal of Business Management, 5(12), 4873-4882. 